\title{
Incidence of Arbuscular Mycorrhizal Fungi in Indian Squill: Drimia indica from Coastal Sand Dunes of Konkan, India
}

\author{
Vishal R. Kamble ${ }^{1}$, Dinesh G. Agre ${ }^{2}$ and Ghansham B. Dixit ${ }^{3}$ \\ ${ }^{1-2}$ (Department of Botany, Bhavan's College Andheri (West), Mumbai- 400058 (MS) India.) \\ ${ }^{3}$ (Department of Botany, Shivaji University, Kolhapur- 416004 (MS) India.)
}

\begin{abstract}
Drimia indica (Roxb) Jessop. (Family: Hyacinthaceae), is also known as Indian squill. Due to over exploitation and anthropogenic pressures such as habitat degradation many populations of $D$. indica have been lost and caused genetic depletion as well as loss of genetic diversity. Hence, it is necessary to initiate new means and approaches are to be worked out for germplasm conservation and sustainable utilization of this economically important medicinal plant. In present paper an attempt has made to study remarkably ignored Arbuscular mycorrhizal (AM) fungi with D. indica.. Mycorrhizal colonization percentage in D. indica samples was varied in different populations in the coastal sand of Konkan region of Maharashtra. In present paper besides the roots, incidence of mycorrhizal colonization and spores inside the D. indica scale cells is reported for first time.
\end{abstract}

Keywords: Acaulospora scrobiculata, AM fungi, CSDs, Drimia indica (Roxb) Jessop. Glomus aggregatum .

\section{Introduction}

Drimia indica (Roxb) Jessop (Family: Hyacinthaceae) (= Urginea indica Kunth.) is commonly known as Indian squill. It is a perennial bulbous geophyte with fibrous roots of six to ten inches of length. It is endemic to India, Africa and Meditteranian Regions [16]. The genus Drimia (Syn. Urginea) has been extensively studied for biosystematics [16], [32], [33]; cytological [3], [28], [29], [30], [36], [39]; cytotaxonomical-genetical aspects [4], [31] and very recently for DNA bar-coding as well as for molecular markers (ITS and $m a t K$ ) [5], [20]. Ethno-medicinally bulbs of $D$. indica has proved antiulcerous, antinematodal, antitumorous, anthelmintic antiarthrities properties and also used to cure skin diseases like warts, abscesses, boils, cardiac diseases, antidote to scorpion sting [18]. The bulbs contain literally hundreds of compounds that defend cells against attack by Marauding free radicals by blocking the development of heart diseases, cancer, Rheumatism dropsy, edema, gout. Asthma, Dog bites, cut wound, infertility in man and numerous other life shortening aliments. Due to these medicinal properties of $D$. indica bulbs have found its place in British and European Pharmacopeias [17].

Unfortunately, many populations of Indian squill, have been lost lost due to unawareness and over exploitation. As per IUCN criteria, Threat status of $D$. indica is VULNERABLE/R (A 1a, 1c, 1d) for Chhattisgarh and Madhya Pradesh [11]. Although, according to Gokhale et. al. [19], D. indica occurs frequently along sand dunes and sandy beaches of Maharashtra, the threatened status of this important plant cannot be ignored at any cost. Hence, it is necessary to initiate awareness, conservation and cultivation of Indian squill. Anthropogenic pressures such as habitat degradation are largely responsible for genetic depletion and loss of genetic diversity [16]. There is urgent need of new means and approaches are to be worked out for germplasm conservation and sustainable utilization of this economically important medicinal plant. It is now well established that, the understanding of mycorrhizal associations in coastal sand dune (CSD) plants and their distribution in the soil is necessary for the sustainable management of these habitats [1]. Although Arbuscular mycorrhizal (AM) fungi are important to the persistence of coastal sand dune vegetation, inventory on coastal sand dune AM fungi in India is very recent [12], [13], [34], [37], [38], [41]. However, little is known about the diversity of AM fungi in medicinal plants from Indian coastal sand dune habitats in general with few exceptions particularly from CSDs of Maharashtra [40], [42]. The objective of the study was to assess the presence and diversity of AM fungi associated with the Indian squill from coastal sand of Konkan region, India.

II. Material And Methods

The traditional taxonomy methods, based on root screening, and spore morphology were used to identify the AM fungal species associated with $D$. indica found in, two sandy beaches and coastal sand dunes adjoining to them from Konkan region of Ratnagiri District, Maharashtra (India) viz., Madban (16 $34^{\prime} 41^{\prime \prime}$, North $73^{\circ} 20^{\prime} 39^{\prime \prime}$ East) and Are Ware (17 $02^{\prime} 09^{\prime \prime}$ North $73^{\circ} 17^{\prime} 45^{\prime \prime}$ East) respectively during 2010-2011. 


\subsection{AM fungal colonization status}

10-20 underground bulbs of plants were removed from sand and after collecting the desired roots or scales again buried to nurture in their natural habitat. Root samples, scales on bulbs surface and rhizospheric sand sample $(500 \mathrm{~g})$ per each plant were brought to the laboratory. Roots and scales were made free from sand and debris to process and stain with slight modifications in techniques of Phillips \& Hayman [9] and Koske \& Gemma [25]. Stained roots were observed under a binocular microscope to evaluate mycorrhizal colonization [15].

\subsection{AM fungal species identification}

Spores were isolated from Rhizopheric sand of plant with the help of wet sieving and decanting method [10]. The morphological properties of spores is based on observations of specimens mounted in polyvinyl alcohol-lactic acid-glycerol (PVLG) [24], in a mixture of PVLG and Melzer's reagent [14], a mixture of lactic acid to water at 1:1, Melzer's reagent, and in water. Spores mounted in Melzer's reagent were crushed in order to observe the staining of the different spore wall layers. Identification of AM fungi is followed after the original descriptions [21], [35]. Spores mountings in PVLG and the mixture of PVLG and Melzer's reagent (air-dried slides) were deposited at Bhavan's Mycorrhizal herbarium (BMH) Mumbai.

\section{Results And Discussion}

Although, the Indian squill: D. indica has been investigated for various parameters [3], [4], [5], [16], [20], [28], [29], [30], [31], [32], [33], [36], [39] howerver the AM fungal status in it has been found quite ignored with very few exceptions. Earlier studies of Parameswaran and Augustine [22], suggested AM fungal distribution and ecology of Urginea indica in scrub jungle from Tamil Nadu and also in few populations by Shiva Kameshwari [17] in non-coastal sand dune regions. However, these studies are not enough to provide specific details of mycorrhizal colonization pattern or morpho-taxonomical details of AM fungal spores. Although, most studies on AM fungi of coastal dunes are confined to temperate regions, and subtropical regions [23], and few were performed from the tropical coast of Hawaiian Islands [26], [27] and Singapore [6]. These studies have added significant data on various plant species but the identity of AM fungal species in $D$. indica is not yet known. Thus, present paper provides comprehensive information on incidence of AM fungi in $D$. indica found in coastal sand dunes of Konkan region of Maharashtra, India and hence makes first report for global AM fungal data base. Results obtained suggests that, AM fungi were colonized in the roots of all samples (Fig. 1) studied from site 1-Madban beach and site 2-Are Ware (henceforth, referred as $S 1$ and $S 2$ respectively). The samples of $D$. indica from both the study sites exhibited all components of mycorrhiza (vesicles, arbuscules and hyphae) with variation in occurrence intensity (Table 1). There was considerable variation in percentage colonization of AM fungi in $D$. indica root samples from both the sites. Although, $S 2$ was showing higher colonization but $S 1$ rhizosphere was comparatively enriched with higher spore count. Hence, to find out any correlation or to make any conclusion for theses variations is very difficult; however, the most probable justification for it may be certain ecological or other factors. Besides the normal pattern of vesicles, grape bunch like clustered vesicles (cv) were also colonizing cortical cells of root in both the samples, their occurrence was also confirmed in scales of $S 2$ samples. Scale cells were also colonized with other endophytic fungi (oef) particularly in some $S 1$ samples. Scales of $S 2$ were also more frequently encountered with spores.

Previously, the occurrence of AM fungi in roots has been reported from an exceptionally wide range of plants. Besides roots, colonization has been reported in other plant parts [2]. Colonization has also been reported from scales of Colocasia antiquorum, Elettaria cardamomum, Musa paradisica, Sanseviera trifaciata, garlic, and ginger [7], [8]. In present paper, incidence of mycorrhizal colonization and spores inside the D. indica scale tissue is reported for first time. In present study, AM fungal species observed in rhizhosphere samples of $D$. indica were belonging to four genera viz., Acaulospora, Gigaspora, Glomus and Scutellospora which represents 9 species. The spores of all nine AM fungal species are presented in Fig. 2 from morpho-taxonomical point of view. From S1 rhizospheres collectively 367 spores belonging to six species were recorded. Whereas, $S 2$ rhizospheres collectively exhibited 270 spores representing all nine species (Table 2). Amongst the nine species $A$. scrobiculata and $G$. aggregatum were dominating the rhizosphere of $D$. indica in the coastal sand dune habitat from Konkan region of Maharashtra. The prevalence of G. aggregatum was also recorded in the scales of $S 2$ samples. The results obtained also suggests that Glomus species were most frequently encountered (58\%) followed by Acaulospora (29\%) Gigaspora (11\%) and Scutellospora spp. (2\%) in D. indica rhizosphere samples. 
I.

FigURES AND TABLES
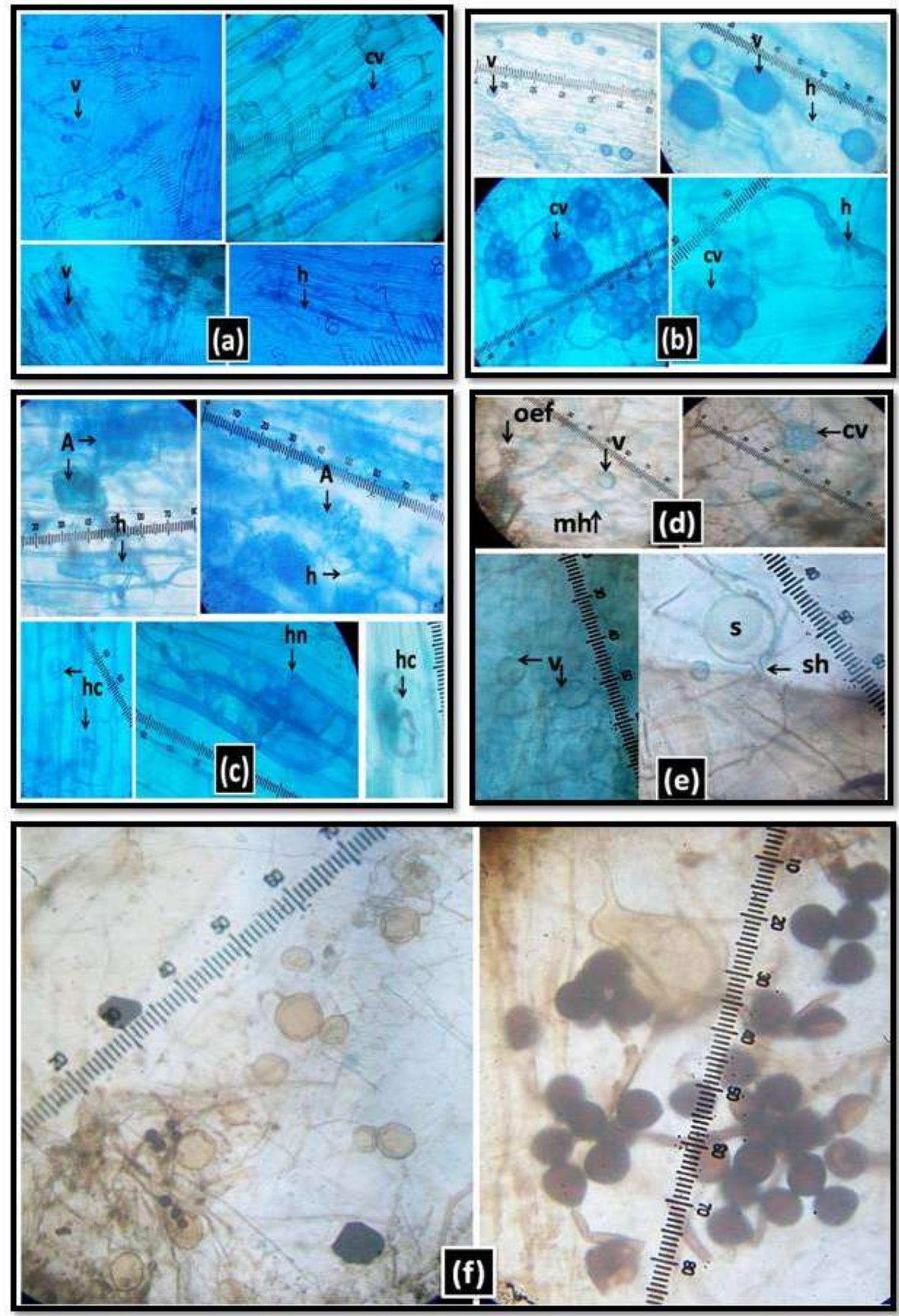

Figure 1 

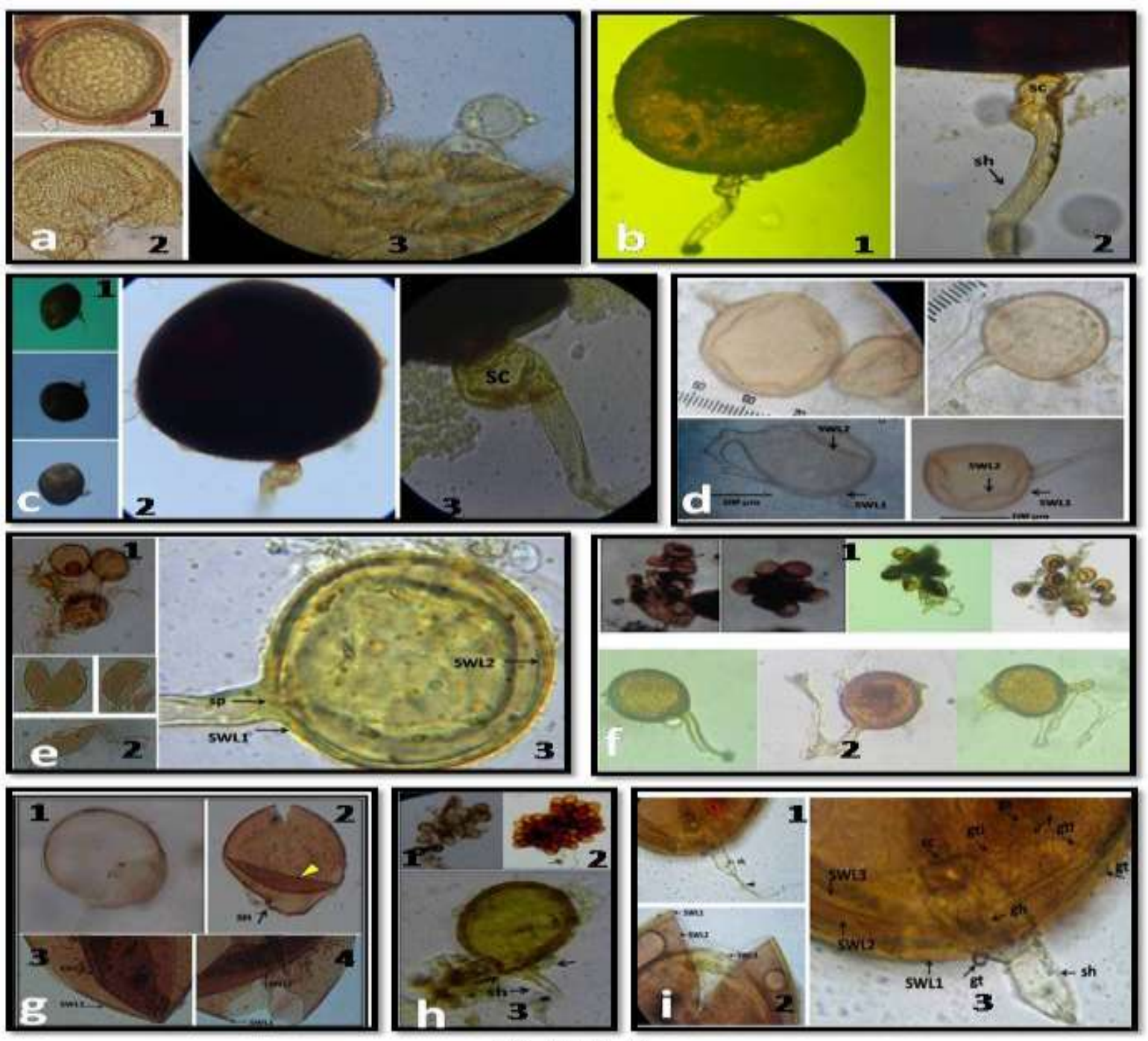

Figure

Figure 1. Mycorrhizal colonization in Drimia indica: Roots (a-c) and Scales of bulbs (d-f) showing: A: arbuscules; cv: clustered vesicles; h: hyphae; hc: hyphal coiling; hn: hyphal net; mh: mycorrhizal hyphae; oef: other endophytic fungi; s: chlamydospores; sh: subtending hyphae of spore and v: vesicles. [Note spore cluster of Glomus aggregatum (f); $S 1$ samples (a \& d), $S 2$ samples (b, c, e \& f)].

Figure 2. Morpho-taxonomical details of AM fungal species associated with Drimia indica from Coastal Sand Dunes of Konkan, India: (a) Acaulospora scrobiculata Trappe: 1. Young spore, 2. Broken spore, 3. Enlarged view of spore; (b) Gigaspora gigantea (Nicol. \& Gerd.) Ger \& \& Trappe: 1. Single spore formed terminally on a bulbous sporogenous cell, 2. Enlarged view of sporogenous cell (sc) and subtending hypha (sh); (c) Gigaspora rosea Nicol. \& N.C. Schenck: 1. Different spores produced singly on the apex of bulbous suspensor cell, 2. Enlarged view of spore with globose to subglobose suspensor cell, 3. Enlarged view of spores base with bulbous suspensor cell (sc). (d) Glomus aggregatum Schenck \& Smith: Spores with subtending hyphae and spore walls (SWL1 \& SWL2); (e) Glomus ambisporum Smith \& Schenck: 1. Spores with subtending hyphae 2. Crushed spores, 3. Enlarged spore with two wall layers (SWL1 \& SWL2) and a small, bridging septum (sp); (f) Glomus formosanum Wu \& Chen.: 1. Spores in broken sporocarps, 2. Enlarged view of spore showing attachments of 1-4 subtending hyphae; (g) Glomus goaensis Khade: 1. Young spore with hypha, 2. Mature spore showing the insertion of hypha $(\mathrm{SH})$ at base and sloughed spore wall from the base of the spore towards the apex (arrow headed), 3-4. Enlarge view of spore walls; (h) Glomus pachycaulis (Wu \& Chen) Almeida \& Schenck: 1-2. Young golden yellow sporocarp with ellipsoidal chlamydospores borne terminally on subtending (arrow) non septate hypha (1- PVLG mount, 2- PVLG + Melzer's reagent), 3. A golden yellow young spore partially enclosed in a thin network of tightly oppressed hypha (arrows), short subtending hypha (sh) with lumen (3); (i) Scutellospora spp. (Unidentified): 1. Single spore formed on cylindrical sporogenous cell (sc) which is terminally formed on the subtending hypha ( $\mathrm{sh}$ ) that arises from mycelia hypha (black arrow headed), and also 
note germ shield (red bordered arrow headed). 2. Crushed spore showing: one outer (SWL1), one middle (SWL2) and one inner (SWL3) spore wall, 3. Enlarged view of spore showing: spore walls (SWL1-SWL3); yellow-brown to brown germination shields (gs) showing 4-6 compartments, separated by large folds (f); often one initial germ hole (gh); germ tubes initiations (gti) are rarely visible from where the germ tubes (gt) may arise (germination visible in figure); bulbous sporogenous cell (sc) and subtending hypha (sh).

Table 1: AM fungal colonization in Indian squill: $D$. indica from CSDs of Konkan

\begin{tabular}{|c|c|c|c|c|c|c|}
\hline \multirow[t]{2}{*}{ SrNo. } & \multirow[t]{2}{*}{ Drimia indica samples-sites } & \multicolumn{3}{|c|}{$\begin{array}{l}\text { "Occurrence intensity of AM } \\
\text { fungi }\end{array}$} & \multirow{2}{*}{$\begin{array}{c}\text { Percentage } \\
\text { colonization } \\
(\%)\end{array}$} & \multirow{2}{*}{$\begin{array}{l}\text { Net Total of } \\
\text { spores } \\
\text { encountered in } \\
\text { rhizosphere }\end{array}$} \\
\hline & & Vesicles & $\begin{array}{l}\text { Arbuscule } \\
\text { s. }\end{array}$ & Huphae & & \\
\hline 1. & $\begin{array}{l}\text { S1- Madban }\left(16^{\circ} 34^{\prime} 41^{\prime \prime} \mathrm{N}\right. \\
\left.73^{\circ} 20^{\prime} 39^{\prime \prime} \mathrm{E}\right)\end{array}$ & + & + & $+1+$ & 41.66 & 367 \\
\hline 2. & $\begin{array}{l}S 2 \text { - Are Ware }\left(17^{\circ} 02^{\prime} 09^{\prime \prime} \mathrm{N}\right. \\
\left.73^{\circ} 17^{\prime} 45^{\prime \prime} \mathrm{E}\right)\end{array}$ & $+1+$ & $+1+$ & $+1+1$ & 74 & 270 \\
\hline
\end{tabular}

$\left[*{ }^{*}(+) 1-25 \%\right.$ : Poor; (++) 25-50\%: Moderate; $(+++)$ 50-75\%: good; $(++++)$ more than $75 \%$ : Excellent]

Table 2: AM fungal species associated with Indian squill: D. indica from CSDs of Konkan

\begin{tabular}{|c|c|c|c|c|c|c|}
\hline \multirow[t]{2}{*}{$\begin{array}{l}\text { Sr } \\
\text { No. }\end{array}$} & \multirow[t]{2}{*}{ AM fungal species } & \multicolumn{2}{|c|}{$\begin{array}{l}\text { Ancidence of } \\
\text { AM fungal } \\
\text { species }\end{array}$} & \multicolumn{2}{|c|}{$\begin{array}{l}\text { No. of AM fungal } \\
\text { spores } 10^{-1} \mathrm{~g} \\
\text { sand }\end{array}$} & \multirow{2}{*}{$\begin{array}{l}\text { Gross } \\
\text { Total of } \\
\text { spores } \\
(S 1+S 2)\end{array}$} \\
\hline & & S1 & $=S 2$ & S1 & $=S 2$ & \\
\hline 1. & Acaulosperascrebiculata Trappe & $\sqrt{ }$ & $\sqrt{ }$ & 120 & 65 & 185 \\
\hline 2 . & Gigasporagigantea (Nicol. \& Gerd.) Ger . \& Trappe & $\sqrt{ }$ & $\sqrt{ }$ & 32 & 17 & 49 \\
\hline 3. & Gigasperaroseq Nicol. \& N.C. Schenck & $\sqrt{ }$ & $\sqrt{ }$ & 03 & 20 & 23 \\
\hline 4. & Glomus aggregatum Schenck \& Smith & $\sqrt{ }$ & $\sqrt{ }$ & 101 & 105 & 206 \\
\hline 5. & Glomus ambisperum Smith \&. Schenck & $\mathrm{x}$ & $\sqrt{ }$ & 00 & 03 & 03 \\
\hline 6. & Glomus formesanum Wu \& Chen. & $\sqrt{ }$ & $\mathrm{x}$ & 79 & 00 & 79 \\
\hline 7. & Glomus goqunsis Khade. & $\sqrt{ }$ & $\sqrt{ }$ & 32 & 15 & 47 \\
\hline 8. & Glomus pachycaulis (Wu \& Chen) Almeida \& Schenck & $\mathrm{x}$ & $\sqrt{1}$ & 00 & 35 & 35 \\
\hline 9. & Scutellespera spp. & $\mathrm{x}$ & $\sqrt{ }$ & 00 & 10 & 10 \\
\hline \multicolumn{4}{|c|}{ Net Total of spores encountered in $D$. indica rhizosphere } & 367 & 270 & 637 \\
\hline
\end{tabular}

\section{Conclusion}

The findings in present study, has added significant information to existing data and hence proposing that Indian squill found in coastal sand dunes are enriched with AM fungal species. Thus with the help of potential of AM fungi in stabilizing the disturbed habitats and in conservation of vulnerable species, like $D$. indica is possible in future. Hence, initiation of isolation of such native AM fungal species in pure form is the need of time. New means and approaches are to be worked out for germplasm conservation and sustainable utilization of this economically important medicinal plant for which native AM fungal isolates can serves functional role. Hence extension of research program is required to obtain native AM fungal inoculum in future on urgent basis.

\section{Acknowledgements}

VRK is personally grateful to Late Prof. (Dr.) T. M. Patil (Dept. of Botany S.U.K.), for his inspiration. Thanks are due to Principal (Dr.) Mrs. V.I. Katchi, B.C.A. (W) Mumbai for providing laboratory facilities, and also due to Principal (Dr.) D.D. Kuralapkar, Marathe College Rajapur for his cooperation during field visits. Our special thanks are due to Late Dr. V.N. Naik, Dr. B.A.M. University for his taxonomical discussions on plant material under study.

\section{References}

[1] A. Camprubí, C. Calvet, P. Cabot, M. Pitet and V. Estaún, Arbuscular mycorrhizal fungi associated with psammophilic vegetation in Mediterranean coastal sand dunes. Spanish Journal of Agricultural Research, 8(S1): 2010, S96-S102.

[2] C. Manoharachary, A. Adholeya, I.K. Kunwar, Mycorrhiza: some glimpses. Mycorrhiza News 20(4): 2009, 1-6.

[3] D. Subramanian, Cytogenetical studies in Urginea indica (Roxb.) Kunth. J. Ind. Bot. Soc. 57: 1978, $211-218$. 
[4] G.B. Dixit and S.R. Yadav, Cytotaxonomical and Genetical Studies in Urginea Steinh. Species from India, Cytologia 54: 1989, 715-721.

[5] H.M. Kawalkar, N.S. Desai, and G.B. Dixit. DNA Barcoding and Molecular Phylogenetics in Indian Drimia species. Abstract in: XI Int. Conf. of IOPB-Evolution of plants from tropical to high mountain ecosystem: Focus on Asia, Dr. B.A.M. University Aurangabad- $2^{\text {nd }}$ to $4^{\text {th }}$ Sep. 2010.

[6] I. Louis, A mycorrhizal survey of plant species colonizing coastal reclaimed land in Singapore, Mycologia, 82: 1990, $772-778$.

[7] I.K. Kunwar and C. Manoharachary, Colonization by arbuscular mycorrhizal and mycophyllous fungi in roots and scale leaves of garlic, J. Ind. Bot. Soc., 77: 1998, 201-203.

[8] I.K. Kunwar and C. Manoharachary, Colonization of the roots, rhizomes and scale like leafs of ginger by arbuscular fungi, Proc. Nat. Sympo. on Fungi in Diversified Habitats, Hyderabad: Osmania University, (Ed.) C. Manoharachary, 1999, $31-36$.

[9] J.M. Phillips, and D.S. Hayman, Improved procedure for clearing roots and staining parasitic and vesicular arbuscular mycorrhizal fungi for rapid assessment of infection, Trans. Br. Mycol. Soc., 55: 1970, $158-161$.

[10] J.W. Gerdemann, and T.H. Nicolson, Spores of mycorrhizal Endogone species extracted from soil by wet sieving and decanting, Trans. Br. Mycol. Soc., 46: 1963, 235-244.

[11] K.C. Joshi, M.S. Negi and A.D. Tiple, Achanakmar-Amarkantak Biosphere Reserve. Biosphere Reserve Information Series (BRIS), 2(1-2), (Tropical Forest Research Institute Jabalpur, 2010, pp. 1-158).

[12] K.R. Beena, N.S. Raviraja and K.R. Sridhar, Association of arbuscular mycorrhizal fungi with Launaea sarmentosa on maritime sand dunes of west coast of India, Kavaka 25: 1997, 53-60.

[13] K.R. Beena, N.S. Raviraja, A.B. Arun and K.R. Sridhar, Diversity of arbuscular mycorrhizal fungi on the coastal sand dunes of west coast of India, Current Science 79: 2000, 1459-1466.

[14] M. Brundrett, L. Melville, L. Peterson, Practical Methods in Mycorrhizal Research. Mycologue Publications, (University of Guelph, Guelph, Ontario, 1994).

[15] M. Giovannetii and B. Mosse, An evaluation of techniques for measuring vesicular - arbuscular mycorrhizal infection in roots, New Phytol. 84: 1980, 489 - 500.

[16] M.N. Shiva Kameshwari, A.B. Lakshman and G. Paramasivam, 2012, Biosystematics studies on medicinal plant Urginea indica Kunth. liliaceae - A review. Int. J. of Pharm. \& Life Sci., 3 (1): 2012, 1394-1406.

[17] M.N. Shiva Kameshwari, Biosystematics studies on Urginea indica Kunth. Liliaceae. (Abs) Nat. Conf. on Forest Biodiversity Resources: Exploitation Conservation \& Management, 21-22 March 2006 CBFS, Madurai Kamaraj University: Madurai, 24-25.

[18] M.S. Chittoor, A.J. Roger Binny, S. Yadlapalli, A. Cheruku, C. Dandu, and Y. Nimmanapalli, Anthelmintic and antimicrobial studies of Drimia indica (Roxb.) Jessop. bulb aqueous extracts Journal of Pharmacy Research, 5(5): 2012, $3677-3686$.

[19] M.V. Gokhale, S.S. Shaikh, N.S. Chavan, Floral survey of wet coastal and associated ecosystems of Maharashtra, Indian Journal of Geo Marine Sciences, 40 (5): 2011, 725-730.

[20] N. Desai, H. Kawalkar, and G. Dixit, Biosystematics and evolutionary studies in Indian Drimia species. Journal of Systematics and Evolution, 50 (6): 2012, 512-518.

[21] N.C. Schenk, and Y. Perez, Manual for the identification of VA - Mycorrhizal fungi, 3rd Ed, (University of Florida, Gainesville, Florida, 1990).

[22] P. Parameswaran and B. Augustine, Distribution and ecology of a VAM in a scrub Jungle. Proc. First Asian conference on Mycorrhizae, C.A.S. in Botany, Madras, (Eds.) A. Mahadevan, N. Raman \& K. Natrajan, 29-31, January 1988, 91-94.

[23] P.J. Lee and R.E. Koske, Gigaspora gigantea seasonal abundance and aging of spores in a sand dune, Mycol Res, 98: 1994, 453457.

[24] R.E Koske and B. Tessier, A convenient, permanent slide mounting medium. Mycol. Soc. Am. Newsletter 34: $1983,59$.

[25] R.E Koske and J.N. Gemma, A modified procedure for staining roots to detect VA mycorrhizas. Mycol Res, 92: 1989, $486-488$.

[26] R.E Koske and J.N. Gemma, Arbuscular mycorrhizal fungi in Hawaiian sand dunes: Islands of Kaua'I, Pacific Science, 50: 1996, $36-45$.

[27] R.E Koske and J.N. Gemma,. VA mycorrhizae in strand vegetation of Hawaii: Evidence for long distance co-dispersal of plants and fungi, Am. J. Bot., 77: 1990, 466-474.

[28] S. Jha and S. Sen, Chromosome study of diploid Indian squill. Cytologia , 48: 1983, 79-86.

[29] S. Jha and S. Sen, Chromosome study of polyploid Indian squill, Urginea indica Kunth. Cytologia 48: 1983, 407-418.

[30] S. Sen, Nature and behaviour of B-chromosomes in Allium stracheyii and Urginea indica Kunth. Cytologia 39: 1974, $245-251$.

[31] S.R. Yadav and G.B. Dixit, Cytotaxonomical Studies in Indian Urginea Steinhill Species, Cytologia 55: 1990, 293-300.

[32] S.R. Yadav, Biosystematic studies on Members of Family Hyacinthaceae in Indian subcontinent. Abstract in: XI Int. Conf. of $I O P B-E v o l u t i o n$ of plants from tropical to high mountain ecosystem: Focus on Asia, Dr. B.A.M. University Aurangabad- $2^{\text {nd }}$ to $4^{\text {th }}$ Sep. 2010.

[33] S.R. Yadav, Biosystematics of Drimia (Hyacinthaceae) species in India. Proc. $99^{\text {TH }}$ Indian Science Congress, Part II: Abstract of Symposium/Invited Lecture, 2012, 251-252.

[34] S.S. Kulkarni, N.S. Raviraja and K.R. Sridhar, Arbuscular mycorrhizal fungi of tropical sand dunes of west coast of India. Journal of Coastal Research, 13: 1997, 931-936.

[35] S.W. Khade, Arbuscular mycorrhizal fungi in wild banana II: a new species (Glomus goaensis Khade sp. nov) Mycorrhiza News 20(4): 2009, 21-22.

[36] T.S. Raghavan, Observations on the somatic chromosomes of Urginea indica Kunth. J. Ind. Bot. Soc. 14: 1935, 151-158.

[37] V. Jaiswal and B.F. Rodrigues, Occurrence and distribution of arbuscular mycorrhizal fungi in coastal sand dune vegetation of Goa, Current Science, 80(7): 2001, 826-827.

[38] V. Mohankumar, S. Ragupathy, C.B. Nirmala and A. Mahadevan, Distribution of vesicular arbuscular mycorrhizae (VAM) in the sandy beach soils of Madras coast. Current Science, 57: 1988, 367-368.

[39] V.N. Naik, Cytotaxonomic studies in two species of Urginea Steinh. from India. J. Ind. Bot. Soc. 55: 1976, 60-64.

[40] V.R. Kamble, B.K. Sayed and N. Qureshi, Screening of CSDPs for AM Fungal Association from Arnala and Kalamb Beach Maharashtra. IOSR Journal of Pharmacy and Biological Science, 2(4): 2012a, 44-47.

[41] V.R. Kamble, D. Thangadurai, H. L. Rahate and D. G. Agre, Status of AM Fungi in Some Medicinal Plants from Panambur Beach Mangalore India. IOSR Journal of Pharmacy and Biological Sciences 3(4): 2012b, 01-04.

[42] V.R. Kamble, D.G. Agre and H. Rahate, Arbuscular Mycorrhizal in some medicinal plants found in sand dunes from Revdanda coast of Maharashtra, Proc. 1st Nat Symp. of SAB on Innovative and Modern Technologies for Agricultural Productivity, Food security and Environment Management, Mangalore, India, 2011, 147-148. 